\title{
Effects of intrapopulation phenotypic traits of invasive crayfish on leaf litter processing
}

\author{
Francisco Carvalho 1 - Cláudia Pascoal · Fernanda Cássio · Ronaldo Sousa
}

Received: 25 July 2017/Revised: 18 April 2018/Accepted: 21 April 2018/Published online: 30 April 2018

(C) Springer International Publishing AG, part of Springer Nature 2018

\begin{abstract}
The impact of invasive alien species (IAS) on an ecosystem is primarily studied at the species level, whereas the functional impacts of their genetic and phenotypic traits are poorly investigated. We used two laboratory based experiments to assess how intrapopulation phenotypic traits (size, sex, and number of claws) of the invasive red swamp crayfish Procambarus clarkii affect invertebrate shredders and leaf processing. Leaf consumption was significantly affected by the size and number of claws but not by the sex of the crayfish. Bigger animals presented a higher overall consumption but, in contrast, the mass of leaves consumed per unit crayfish body mass decreased with size. Indeed, the production of particulate organic matter followed the same trend,
\end{abstract}

Handling editor: Verónica Ferreira

F. Carvalho $(\bowtie) \cdot$ C. Pascoal · F. Cássio · R. Sousa Department of Biology, CBMA - Centre of Molecular and Environmental Biology, University of Minho, Campus de Gualtar, 4710-057 Braga, Portugal e-mail: fcarvalho@bio.uminho.pt

F. Carvalho · C. Pascoal · F. Cássio - R. Sousa

IB-S, Institute of Science and Innovation for BioSustainability, University of Minho, Campus de Gualtar, 4710-057 Braga, Portugal

\section{R. Sousa}

Interdisciplinary Centre of Marine and Environmental Research (CIIMAR/CIMAR), University of Porto, Rua dos Bragas 289, 4050-123 Porto, Portugal suggesting that the higher metabolic needs of smaller animals are responsible for their higher feeding activity on leaf litter. Claw loss in P. clarkii also led to increased leaf consumption and may be related to increased energy requirements for claw regeneration. Our results highlight the importance of also considering the phenotypic traits within populations for better understanding the impacts of IAS on ecosystem processes.

Keywords Ecosystem processes - Intraspecific variation - Invasive alien species - Procambarus clarkii $\cdot$ Streams

\section{Introduction}

Natural populations are usually composed of genetically and phenotypically distinct organisms that exhibit variations in morphological, behavioral and/ or physiological traits (Bolnick et al., 2011; Sih et al., 2012). This intraspecific phenotypic variation is widely studied in evolution since it constitutes the foundation for natural selection (Bolnick et al., 2011). However, it is often assumed that conspecific individuals are phenotypically uniform, and so they would affect ecosystem functioning in a similar way (Hairston \& Hairston, 1993). This assumption may be misleading because intraspecific variations can alter 
biotic interactions (Bolnick et al., 2011), although few studies have addressed their effects on ecosystem functioning (but see e.g., Post et al., 2008; Harmon et al., 2009; Palkovacs \& Post, 2009; Bassar et al., 2010; Palkovacs et al., 2015). For example, sex ratio variation and sexual dimorphism were shown to shape the effects of an introduced freshwater fish on zooplankton and phytoplankton abundance and productivity, inducing pelagic trophic cascades (Fryxell et al., 2015). Also, synergistic interactions between body size and species identity of a predator dragonfly modulated its functional effects on communities (Rudolf et al., 2014).

The introduction of invasive alien species (IAS) is a major threat to biodiversity (Simberloff et al., 2013). IAS may change biotic interactions, and thus affect several attributes of native communities, with impacts on relevant ecosystem processes and functions (Sousa et al., 2011; Gutiérrez et al., 2014). Invasion biology has focused on functional diversity at or above the species level to explain possible ecological effects in the invaded areas (Hooper et al., 2005; Palkovacs et al., 2009). However, recent studies have demonstrated that intraspecific trait variations in IAS should also deserve attention as they may influence invasion success (Chapple et al., 2012; Forsman, 2014; González-Suárez et al., 2015) and/or modulate ecological impacts (Evangelista et al., 2017).

The red swamp crayfish Procambarus clarkii (Girard, 1852) is a widely distributed IAS in freshwater ecosystems. Native to southern United States of America and north-eastern Mexico, P. clarkii was successfully introduced in Europe in the 1970s (Gherardi, 2006). Its engineering activities and ability to alter biotic interactions make this IAS a cause of great concern in freshwater ecosystems (Loureiro et al., 2015; Souty-Grosset et al., 2016). For example, leaf litter processing is a key ecosystem process driven by microbial decomposers and invertebrate detritivores that control the flux of energy and carbon in aquatic food-webs (Suberkropp, 1998). The omnivorous $P$. clarkii can have a pivotal effect on leaf litter processing through consumption of both leaf litter (i.e., direct effect) and native invertebrate detritivores (i.e., indirect effect) (Alp et al., 2016; Carvalho et al., 2016). This ultimately affects native invertebrate biodiversity (Correia \& Anastácio, 2008) and ecosystem functioning (e.g., organic matter turnover and nutrient cycling; Bernardo \& Ilhéu, 1994; Jackson et al., 2014). Some studies explored the effects of $P$. clarkii sex and size on native invertebrate communities (Correia, 2002, 2003), but the effects of their intrapopulation phenotypic traits on ecosystem functioning, including leaf litter processing, remain poorly studied.

The aim of our study was to assess the effects of the intrapopulation traits of $P$. clarkii on leaf litter processing. We expected that differences in the size and sex of $P$. clarkii would lead to differences in its feeding behavior and leaf litter processing. We also expected that larger animals would consume more leaf litter (Gutiérrez-Yurrita et al., 1998) and consequently produce more particulate organic matter (POM). During the reproductive period, $P$. clarkii individuals are susceptible to lose claws due to increased aggressiveness (Bender, 1971; Juanes \& Smith, 1995) and we hypothesized that this loss of claws would decrease their feeding activity, with consequences on leaf litter processing.

\section{Materials and methods}

Specimens collection

We collected males and females of $P$. clarkii with different total lengths (small $<69 \mathrm{~mm} \pm 10 \mathrm{~mm} \mathrm{SE}$ and big $>108 \mathrm{~mm} \pm 4 \mathrm{~mm} \mathrm{SE}$ ) in the Minho River $\left(41^{\circ} 57^{\prime} \mathrm{N}, 8^{\circ} 44^{\prime} \mathrm{W}\right)$, Portugal. Specimens were collected in a semi-enclosed area (depth variation between 1.5 and $3.0 \mathrm{~m}$ and $14 \mathrm{~km}$ upstream of the river mouth). A full description of the abiotic and biotic conditions of the collection site can be found in Sousa et al. (2013) and Mota et al. (2014). Crayfish were captured with fyke-nets (10-mm mesh, 0.7-mdiameter mouth, 7-m-long, 3.5-m central wing) during their active period (May and June 2013) as described in Sousa et al. (2013).

We collected Sericostoma sp. larvae (Trichoptera, Sericostomatidae), a common invertebrate shredder in northern Portugal, at the upper reach of the Cávado River in May and June 2013. This site is located $10 \mathrm{~km}$ downstream from the town of Montalegre $\left(41^{\circ} 48^{\prime} \mathrm{N}\right.$, $7^{\circ} 51^{\prime} \mathrm{W}$ ), Portugal, where the presence of crayfish (including P. clarkii) is not reported so far. Sericostoma sp. individuals had a total length of approximately $10 \mathrm{~mm}$ (case length). 
Crayfish and Sericostoma sp. individuals were acclimated to laboratory conditions for 7 days before the experiment $\left(15^{\circ} \mathrm{C}\right.$ room temperature, $12 / 12-\mathrm{h}$ photoperiod). During this period, individuals were kept in aquariums (crayfish were kept individually) with 31 of aerated mineral water, and allowed to feed on alder Alnus glutinosa (L.) Gaertn leaves. Individuals of both species were put under starvation for $24 \mathrm{~h}$ before the beginning of the experiments.

\section{Mesocosm experiments}

For both laboratory mesocosm experiments, we used aquariums $(40 \times 23 \times 25 \mathrm{~cm})$ equipped with an aeration system. The mesocosms were filled with 31 of mineral water and the bottoms were covered with sand, gravel, and pebbles (size $850 \mu \mathrm{m}-60 \mathrm{~mm}$ grain size; layer of $2 \mathrm{~cm}$ ), previously washed and autoclaved $\left(120^{\circ} \mathrm{C}, 20 \mathrm{~min}\right)$. Sets of alder leaves, collected in autumn 2012 immediately after abscission, were weighed (mean $=4.01 \mathrm{~g}$ dry weight $\pm 0.01 \mathrm{SE}$ ), placed in mesh bags (green plastic $23 \times 15 \mathrm{~cm}$; $5 \times 5 \mathrm{~mm}$ pore size) and submerged in deionized water for $36 \mathrm{~h}$ to promote the leaching of soluble compounds. The content of each litter bag was then transferred to each mesocosm.

Mesocosms also received leaf discs previously immersed in a stream to ensure the colonization of alder leaves by a natural microbial community. Sets of 10 alder discs (12 $\mathrm{mm}$ diameter) were immersed for 1 week in a low-order stream (Oliveira, $41^{\circ} 35^{\prime} \mathrm{N}$, $8^{\circ} 13^{\prime} \mathrm{W}$ ) and then placed in the mesocosms (one set/ mesocosm) at the beginning of the experiment following Fernandes et al. (2015). Data from leaf discs were not used to calculate leaf litter processing since they were protected from Sericostoma sp and crayfish disturbance and consumption.

In Experiment one, we assessed if size (small $<$ $70 \mathrm{~mm}$ and big $>100 \mathrm{~mm}$ total length) and sex of $P$. clarkii affected leaf consumption and the production of POM. Experimental design consisted of (i) microbial control, without animals; (ii) invertebrate control, 6 Sericostoma sp.; (iii) 1 small crayfish male +6 Sericostoma sp.; (iv) 1 small crayfish female +6 Sericostoma sp.; (v) 1 big crayfish male +6 Sericostoma sp.; and (vi) 1 big crayfish female +6 Sericostoma sp. Crayfish were weighed at the beginning and the end of the experiment.
In Experiment two, we assessed if the number of claws of P. clarkii affected leaf consumption and POM production. We selected males of similar size and with two $\quad($ mean $=98 \mathrm{~mm} \pm 3 \quad \mathrm{SE}$ ), one $\quad($ mean $=96$ $\mathrm{mm} \pm 7 \mathrm{SE}$ ), or no claws (mean $=94 \mathrm{~mm} \pm 4 \mathrm{SE}$ ). The crayfish size did not differ between treatments (one-way ANOVA; $P=0.566 ; F=1.12$;). Experimental design consisted of (i) microbial control; (ii) invertebrate control, 6 Sericostoma sp.; (iii) 1 crayfish without claws +6 Sericostoma sp.; (iv) 1 crayfish with 1 claw +6 Sericostoma sp.; (v) 1 crayfish with 2 claws +6 Sericostoma $\mathrm{sp}$.

Both experiments ran for 21 days and each treatment was replicated 4 times. One-third of the water volume of each mesocosm was renewed every 7 days. The retrieved water (from each renewal and final remaining) was filtered through a $53-\mu \mathrm{m}$ sieve to collect small particles from water suspensions, mainly POM. Then, POM was centrifuged (10 min, 14,000 rpm; Sigma 4-16 K), and the pellet lyophilized (Biolblock Scientific-Christ Alpha 2-4 LD Plus) for $48 \mathrm{~h}$, before being weighed to the nearest $0.01 \mathrm{mg}$. At the end of the experiments, the remaining leaf material was cleaned, dried at $60^{\circ} \mathrm{C}$ for $48 \mathrm{~h}$, and weighed to the nearest $0.01 \mathrm{~g}$. Percentage of leaf consumption $\left(L_{\mathrm{c}}\right)$ was quantified as $L_{\mathrm{c}}=\left(L_{\mathrm{i}}-L_{\mathrm{f}}\right)$ $\times\left(100 / L_{\mathrm{i}}\right)$, where $L_{\mathrm{i}}$ and $L_{\mathrm{f}}$ are the initial and final dry mass (DM, g) of leaves. Leaf consumed per gram of

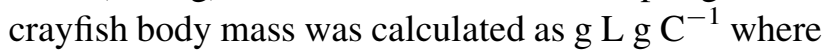
$\mathrm{g} \mathrm{L}$ is the mass of leaf and $\mathrm{g} \mathrm{C}$ is the biomass of crayfish.

\section{Statistical analyses}

Two-way analysis of variance (ANOVA) was used to test if crayfish size and sex affected leaf consumption and POM production (Zar, 2009). One-way ANOVA was used to test if the number of crayfish claws affected leaf consumption and POM production used (Zar, 2009). Moreover, leaf consumption and POM production by the crayfish were compared with microbial control and invertebrate control by oneway ANOVAs. ANOVAs were followed by Tukey's post-tests to determine where significant differences occurred (Zar, 2009).

All ANOVAs were preceded by the Shapiro-Wilk test to check if the residuals of the models had a Gaussian distribution, and the Bartlett test to check for homoscedasticity (Zar, 2009). Residuals were 
normally distributed and variances were homogenous. All statistical analyses were performed using STATISTICA 8 (StarSoft, USA).

\section{Results}

In experiment one, leaf consumption was significantly higher in the presence of big crayfish compared to microbial and invertebrate controls. $(P<0.001$; $F=13.63$ ). Leaf consumption by microbes (microbial control) was $41.4 \% \pm 1.27$ and by the Sericostoma sp. (invertebrate control) was $42.6 \% \pm 1.24$. Leaf consumption was affected by the crayfish size $(P=0.004$; $F=12.41$; Fig. 1A, Table 1) but not by their sex $(P=0.779 ; F=0.08 ;$ Fig. 1 A, Table 1$)$. Big crayfish had higher leaf consumption $(83.5 \% \pm 7.58$ in males and $83.4 \% \pm 3.86$ in females) than small crayfish $(60.2 \% \pm 5.75$ in males; $63.8 \% \pm 6.61$ in females $)$ (Fig. 1A). However, an opposite trend was found when leaf consumption was expressed as grams of leaf consumed per gram of crayfish body mass (Fig. 1B).
Again, the crayfish size $(P=0.002 ; F=14.92)$, but not the sex $(P=0.673 ; F=0.19)$, had a significant effect on leaf consumption (Fig. 1B; Table 1). Leaf consumption per unit body mass decreased with size. Big crayfish processed $0.08 \mathrm{~g} / \mathrm{g} \pm 0.01$ in males, $0.08 \mathrm{~g} / \mathrm{g} \pm 0.01$ leaves in females, while small crayfish processed $0.28 \mathrm{~g} / \mathrm{g} \pm 0.05$ in males and $0.33 \mathrm{~g} /$ $\mathrm{g} \pm 0.10$ in females.

POM production by big crayfish was significantly higher than that by microbes and Sericostoma sp. $(P<0.001 ; F=9.79)$. The microbial control produced $0.15 \mathrm{~g} \pm 0.02$ of POM, and invertebrate control produced $0.11 \mathrm{~g} \pm 0.02$. POM production was affected by the crayfish size $(P=0.003 ; F=14.11$; Fig. 1C; Table 1) but not by the sex $(P=0.486$; $F=0.52$; Fig. $1 \mathrm{C}$; Table 1 ), and it was significantly higher in the presence of big crayfish. POM production was $0.52 \mathrm{~g} \pm 0.11$ in big male crayfish, $0.62 \mathrm{~g} \pm 0.10$ in big female crayfish, $0.27 \mathrm{~g} \pm 0.02$ in small male crayfish, and $0.28 \mathrm{~g} \pm 0.04$ in small female crayfish (Fig. 1C). An opposite trend (i.e., POM production decreased with crayfish size) was

\section{A}

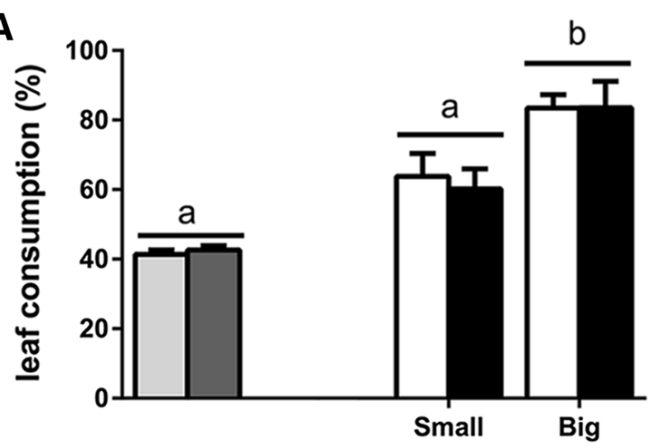

B

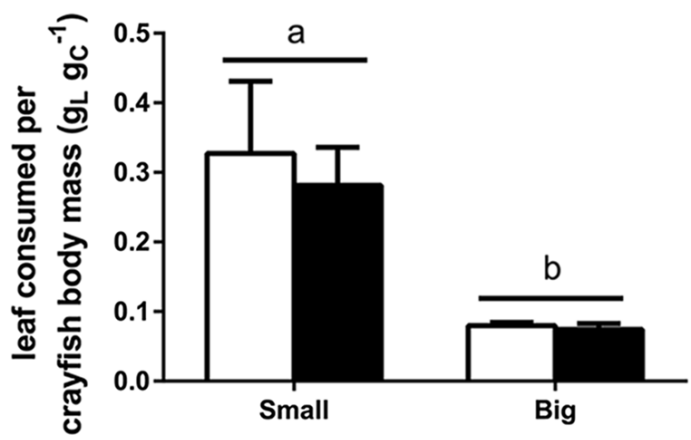

Fig. 1 Effects of sex and size of Procambarus clarkii on percentage of leaf consumption per mesocosm (A), leaf consumed per crayfish wet biomass (B), POM production per mesocosm (C), and POM production per crayfish wet biomass (D) from Experiment 1. Results were also compared to microbial control (mesocosms without Sericostoma sp. or $P$.
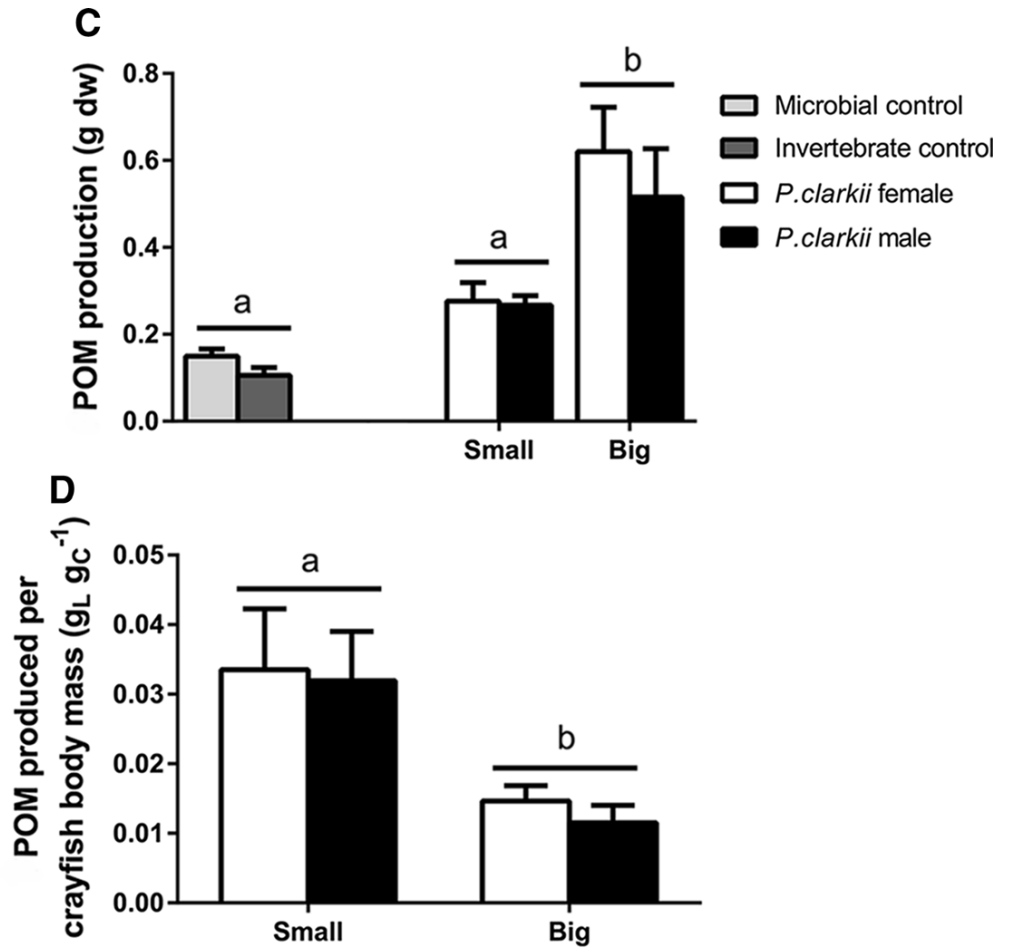

clarkii) and invertebrate control (with Sericostoma sp. only, six individuals). Other mesocosms had 6 larvae of the invertebrate shredder Sericostoma sp. and 1 P. clarkii with different sex and size. Mean \pm SEM, $n=4$. Different letters indicate significant differences between treatments $(P<0.05)$ 
Table 1 Summary statistics of two-way ANOVAs that tested for the effects of Procambarus clarkii sex and size on percentage of leaf consumption, leaf consumed per crayfish biomass and POM production in Experiment 1

\begin{tabular}{llrrr}
\hline Parameter & Effect & $d f$ & $F$ & $P$ \\
\hline Percentage of leaf consumption & Crayfish sex & 1 & 0.08 & 0.779 \\
& Crayfish size & 1 & 12.41 & 0.004 \\
& Crayfish sex $\times$ Crayfish size & 1 & 0.09 & 0.764 \\
Leaf consumed per crayfish biomass & Crayfish sex & 1 & 0.19 & 0.673 \\
& Crayfish size & 1 & 14.92 & 0.002 \\
& Crayfish sex $\times$ Crayfish size & 1 & 0.12 & 0.735 \\
POM production & Crayfish sex & 1 & 0.52 & 0.486 \\
& Crayfish size & 1 & 14.11 & 0.003 \\
& Crayfish sex $\times$ Crayfish size & 1 & 0.37 & 0.556 \\
POM production per crayfish biomass & Crayfish sex & 1 & 0.16 & 0.692 \\
& Crayfish size & 1 & 11.25 & 0.006 \\
& Crayfish sex $\times$ Crayfish size & 1 & 0.02 & 0.897 \\
\hline
\end{tabular}

$0.60 \mathrm{~g} \pm 0.10$ in mesocosms with crayfish without claws. Crayfish claw loss had no effect on the amount of POM produced $(P=0.646 ; F=0.46$; Table 2$)$.

\section{Discussion}

Our results clearly demonstrate that both $P$. clarkii size and number of claws, but not sex, affect leaf litter consumption and POM production. This highlights the importance of intrapopulation phenotypic trait variations of IAS as a driver of ecosystem processes and functions.

Our results suggest that crayfish size was an important trait for leaf processing. Although bigger animals consumed higher amounts of leaf litter, smaller animals showed higher levels of leaf consumption per unit mass. This can be explained by the higher metabolic demands of smaller animals that consume higher amounts of leaf litter per animal biomass as compared to bigger animals (Singer, 2004). Furthermore, since the small crayfish used in this study were not sexually mature, their energetic demands were probably mainly devoted to rapid growth. In addition, and consistent with the results for leaf consumption, bigger animals were found to also produce more POM in our study. Smaller crayfish produced higher POM per body mass, giving further support to the suggestion of higher metabolic and energetic demands for smaller animals. POM plays a key role in freshwater ecosystems as invertebrate collectors depend on this resource (Graça, 2001; Reiss et al., 2010) and our results suggest that alterations in $0.59 \mathrm{~g} \pm 0.12$ in crayfish with one claw, and 

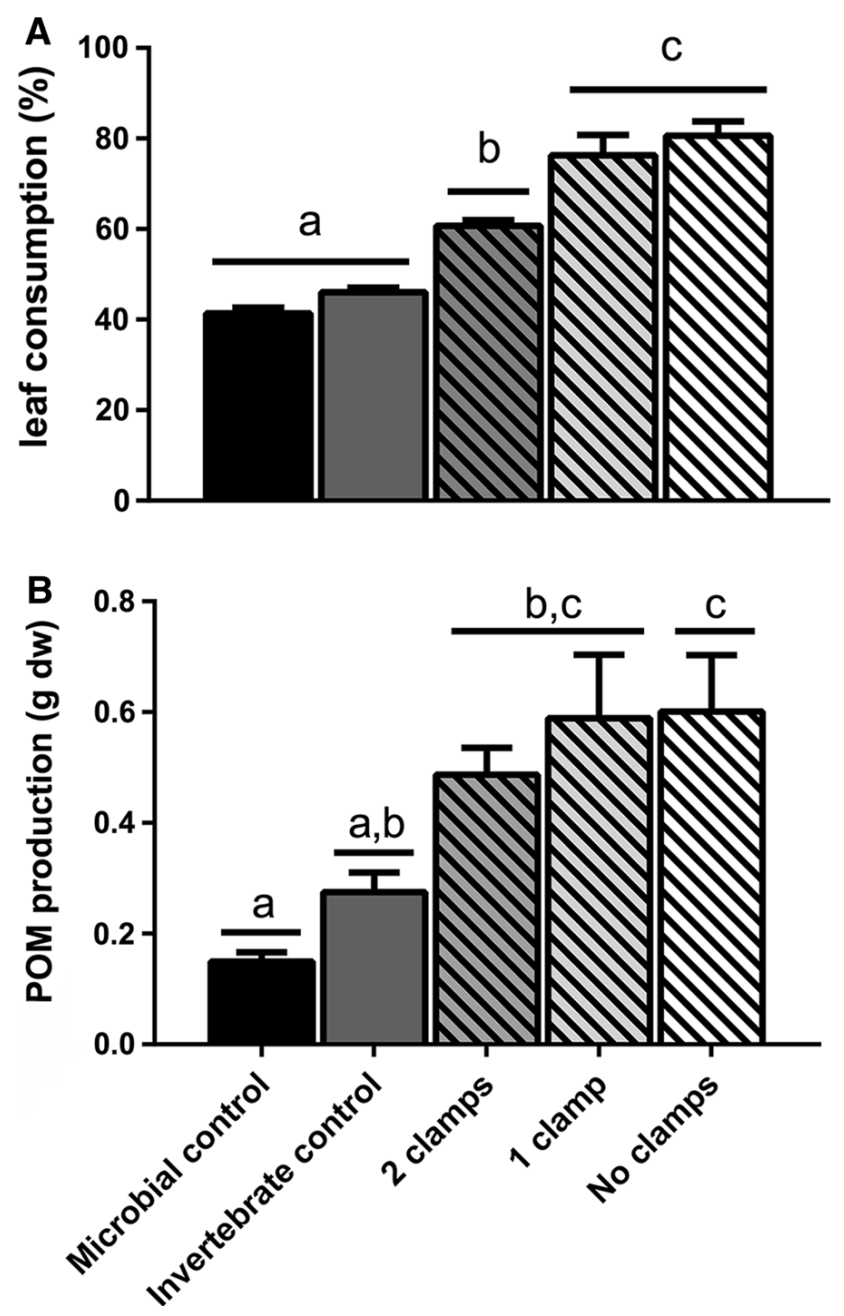

Fig. 2 Effects of claw loss of. Procambarus clarkii on percentage of leaf consumption (A) and POM production (B) per mesocosm from Experiment 2. Results were also compared to microbial control (mesocosms without Sericostoma sp. or P. clarkii) and invertebrate control (with Sericostoma sp. only, 6 individuals). Other mesocosms had P. clarkii with different numbers of claws (none, one, two) in the presence of 6 larvae of the invertebrate shredder Sericostoma sp. Mean \pm SEM, $n=4$. Bars with patterns indicate treatments with the presence of $P$. clarkii. Different letters indicate significant differences between treatments $(P<0.05)$

Table 2 Summary statistics of one-way ANOVAs that tested for the effects of Procambarus clarkii claw loss on leaf consumption and FPOM in Experiment 2

\begin{tabular}{llrl}
\hline Parameter & $d f$ & $F$ & $P$ \\
\hline Leaf processing & 2 & 10.36 & 0.005 \\
POM production & 2 & 0.46 & 0.646 \\
\hline
\end{tabular}

POM production by the crayfish may affect aquatic ecosystems due to changes in quantity and/or quality of food supplies (Dietrich, 1997; Wipfli et al., 2007).

Interestingly, no differences in leaf consumption or POM production were detected according to animal sex under laboratory conditions. Typically, crayfish males are much more aggressive and active than females (Abrahamssom, 1966; Stein \& Magnuson, 1976; Berril \& Arsenault, 1984; Usio \& Townsend, 2002), and this behavior could be expected to translate into higher feeding rates. Moreover, their higher activity and movements could be expected to cause abrasion and contribute to increased leaf processing. Nevertheless, in our case, and as reported by others (Gutiérrez et al., 1998; Correia, 2002, 2003), no differences were observed in diet preferences between $P$. clarkii males and females.

Interestingly, but contrary to that expected, our results showed that crayfish with one or no claws were able to consume more leaves than those with both claws. In addition, while not being significantly different, our results did also indicate that crayfish without both claws tended to produce more POM than crayfish with both claws. Crayfish use claws to grab and collect food resources (Stein, 1976), and thus those without claws would be expected to have a lower capacity for capturing food. Indeed, a previous study demonstrated that the blue crab Callinectes sapidus Rathbun, 1896, without both chelipeds, had lower feeding rates than those with both or just one cheliped (Smith \& Hines, 1991) and this reduction in the feeding capacity continued during the regenerative process (Juanes \& Smith, 1995). In fact, claws have already been shown to make a major contribution to the physiological fitness of adult crayfish (Hudina et al., 2012) and animals with larger claws have advantages in foraging, defense against predators, intraspecific competition, sexual competition, and reproductive success (Garvey \& Stein, 1993; Lee, 1995; Streissl \& Hödl, 2002). Other studies also showed that claw loss in decapod crustaceans affects diet by reducing resource consumption (e.g., Matheson \& Gagnon, 2012), with consequences for growth and regeneration, and leading to changes in population dynamics and community processes (Juanes \& Smith, 1995). Our results contradict these studies but it is possible that this discrepancy is related to the crayfish's capacity for regeneration of its body parts (Cooper, 1998). Indeed, the regeneration of claws, 
which comprise a substantial portion of the total body weight of crayfish, is an energy intensive process (Powell et al., 1998). In addition, crayfish with one or no claws may compensate for this deficiency by using their walking legs to help in feeding (e.g., Smith \& Hines, 1991) since major chelae are used mainly for agonistic encounters whereas minor chelae are used for prey capture and handling (Mariappan et al., 2000). Finally, in the collection site for the crayfish used in this study (River Minho, Iberian Peninsula), up to $40 \%$ of $P$. clarkii males have been reported to have lost one or two claws as a result of increased aggressiveness (Sousa et al., 2013). Therefore, it is conceivable that the crayfish increased feeding on leaf litter, with impacts on leaf processing. Nevertheless, these results should be interpreted with caution because the study was conducted under laboratory conditions, where crayfish were not subjected to competition or predation and were confined to aquarium mesocosms. Also, the crayfish had limited food resources (leaf litter and/ or invertebrate shredders), which is a simplified representation of food resources for an omnivore. Therefore, to better understand the impacts of intrapopulation traits on key ecosystem processes, further studies with $P$. clarkii should be conducted in field mesocosms under different environmental conditions.

In conclusion, our results demonstrate that in freshwater ecosystems, not only the identity of the species, but also their intrapopulation traits, are important predictors of key ecosystem processes including leaf litter consumption and POM production. Therefore, we advocate that intrapopulation trait variation should be considered when assessing the impacts of IAS on native species and ecosystem processes.

Acknowledgements This work was supported by the strategic programme UID/BIA/04050/2013 (POCI-01-0145-FEDER007569) and the FreshBioFun project (PTDC/AAC-AMB/ 117068/2010) funded by the Portuguese Foundation for Science and Technology (FCT), by the Ministério da Ciência, Tecnologia e Ensino Superior (MCTES) and by the European Regional Development Fund (ERDF) through the COMPETE2020 - Programa Operacional Competitividade e Internacionalização (POCI). We acknowledge the anonymous referees and the editor for their constructive suggestions and our colleague Tony Collins for the English revision.

\section{References}

Abrahamsson, S. A. A., 1966. Dynamics of an isolated population of the crayfish, Astacus astacus Linné. Oikos 17: 96-107.

Alp, M., J. Cucherousset, M. Buoro \& A. Lecerf, 2016. Phenological response of a key ecosystem function to biological invasion. Ecology Letters 19: 519-527.

Bassar, R. D., M. C. Marshall, A. López-Sepulcre, E. Zandonà, S. K. Auer, J. Travis, C. M. Pringle, A. S. Flecker, S. A. Thomas, D. F. Fraser \& D. N. Reznick, 2010. Local adaptation in Trinidadian guppies alters ecosystem processes. Proceedings of The National Academy of Sciences 107: 3616-3621.

Bender, E. S., 1971. Studies of the life history of the stone crab, Menippe mercenariu (Say), in the Cedar Key urea. MSc. thesis, University of Florida, Gainesville, Florida.

Bernardo, J. M. \& M. A. Ilhéu, 1994. Red swamp crayfish (Procambarus clarkii): contribution to material cycling. Verhandlungen des Internationalen Verein Limnologie 25: 2447-2449.

Berrill, M. \& M. Arsenault, 1984. The breeding behaviour of a northern temperate orconectid crayfish, Orconectes rusticus. Animal Behaviour 32: 333-339.

Bolnick, D. I., P. Amarasekare, M. S. Araújo, R. Bürger, J. M. Levine, M. Novak, V. H. W. Rudolf, S. J. Schreiber, M. C. Urbah \& D. Vasseur, 2011. Why intraspecific trait variation matters in community ecology. Trends in Ecology \& Evolution 26: 183-192.

Carvalho, F., C. Pascoal, F. Cássio \& R. Sousa, 2016. Direct and indirect effects of an invasive omnivore crayfish on leaf litter decomposition. Science of Total Environment 541: 714-720.

Chapple, D. G., S. M. Simmonds \& B. B. Wong, 2012. Can behavioral and personality traits influence the success of unintentional species introductions? Trends in Ecology \& Evolution 27: 57-64.

Cooper, R. L., 1998. Development of sensory processes during limb regeneration in adult crayfish. Journal of experimental biology 201: 1745-1752.

Correia, A. M., 2002. Niche breadth and trophic diversity: feeding behaviour of the red Swamp crayfish (Procambarus clarkii) towards environmental availability of aquatic macroinvertebrates in a rice field (Portugal). Acta Oecologica 23: 421-429.

Correia, A. M., 2003. Food choice by the introduced crayfish Procambarus clarkii. Annales Zoologici Fennici 40: 517-528.

Correia, A. M. \& P. M. Anastácio, 2008. Shifts in aquatic macroinvertebrate biodiversity associated with the presence and size of an alien crayfish. Ecological Research 23: $729-734$.

Dieterich, M., N. H. Anderson \& T. Anderson, 1997. Shreddercollector interactions in temporary streams of western Oregon. Freshwater Biology 38: 387-393.

Evangelista, C., A. Lecerf, J. R. Britton \& J. Cucherousset, 2017. Resource composition mediates the effects of intraspecific variability in nutrient recycling on ecosystem processes. Oikos 126: 1439-1450. 
Fernandes, I., S. Duarte, F. Cássio \& C. Pascoal, 2015. Plant litter diversity affects invertebrate shredder activity and the quality of fine particulate organic matter in streams. Marine and Freshwater Research 66: 449-458.

Forsman, A., 2014. Effects of genotypic and phenotypic variation on establishment are important for conservation, invasion, and infection biology. Proceedings of the National Academy of Sciences 111: 302-307.

Fryxell, D. C., H. A. Arnett, T. M. Apgar, M. T. Kinnison \& E. P. Palkovacs, 2015. Sex ratio variation shapes the ecological effects of a globally introduced freshwater fish. Proceedings of the Royal Society B: Biological Sciences 282: 1817.

Garvey, J. E. \& R. A. Stein, 1993. Evaluating how chela size influences the invasion potential of an introduced crayfish (Orconectes rusticus). American Midland Naturalist 129: 172-181.

Gherardi, F., 2006. Crayfish invading Europe: the case study of Procambarus clarkii. Marine and Freshwater Behaviour and Physiology 39: 175-191.

González-Suárez, M., S. Bacher \& J. M. Jeschke, 2015. Intraspecific trait variation is correlated with establishment success of alien mammals. The American Naturalist 185: 737-746.

Graça, M. A. S., 2001. The role of invertebrates on leaf litter decomposition in streams-a review. International Review of Hydrobiology 86: 383-393.

Gutiérrez-Yurrita, P. J., G. Sancho, M. A. Bravo, A. Baltana's \& C. Montes, 1998. Diet of the red swamp crayfish Procambarus clarkii in natural ecosystems of the Donana National Park temporary fresh-water marsh (Spain). Journal of Crustacean Biology 18: 120-127.

Gutiérrez, J. L., C. G. Jones \& R. Sousa, 2014. Toward an integrated ecosystem perspective of invasive species impacts. Acta Oecologica 54: 131-138.

Hairston Jr, N. G. \& N. G. Hairston Sr, 1993. Cause-effect relationships in energy flow, trophic structure, and interspecific interactions. The American Naturalist 142: 379-411.

Harmon, L. J., B. Matthews, S. Des Roches, J. M. Chase, J. B. Shurin \& D. Schluter, 2009. Evolutionary diversification in stickleback affects ecosystem functioning. Nature 458: 1167-1170.

Hooper, D. U., F. S. I. I. I. Chapin, J. J. Ewel, A. Hector, P. Inchausti, S. Lavorel, J. H. Lawton, D. M. Lodge, M. Loreau, S. Naeem, B. Schmid, H. Setala, A. J. Symstad, J. Vandermeer \& D. A. Wardle, 2005. Effects of biodiversity on ecosystem functioning: a consensus of current knowledge. Ecological Monographs 75: 3-35.

Hudina, S., K. Hock, K. Žganec \& A. Lucić, 2012. Changes in population characteristics and structure of the signal crayfish at the edge of its invasive range in a European river. Annales de Limnologie - International Journal of Limnology 48: 3-11.

Jackson, M. C., T. Jones, M. Milligan, D. Sheath, J. Taylor, A. Ellis, J. England \& J. Grey, 2014. Niche differentiation among invasive crayfish and their impacts on ecosystem structure and functioning. Freshwater Biology 59: $1123-1135$.

Juanes, F. \& L. D. Smith, 1995. The ecological consequences of limb damage and loss in decapod crustaceans: a review and prospectus. Journal of Experimental Marine Biology and Ecology 193: 197-223.

Lee, S. Y., 1995. Cheliped size and structure: the evolution of a multifunctional decapod organ. Journal of Experimental Marine Biology and Ecology 193: 161-176.

Loureiro, T. G., P. M. Anastácio, P. B. Araujo, C. Souty-Grosset \& M. P. Almerão, 2015. Red Swamp crayfish: biology, ecology and invasion- an overview. Nauplius 23: 1-19.

Mariappan, P., C. Balasundaram \& B. Schmitz, 2000. Decapod crustacean chelipeds: an overview. Journal of Biosciences 25: 301-313.

Matheson, K. \& P. Gagnon, 2012. Temperature mediates noncompetitive foraging in indigenous rock (Cancer irroratus Say) and recently introduced green (Carcinus maenas L.) crabs from Newfoundland and Labrador. Journal of Experimental Marine Biology and Ecology 414: 6-18.

Mota, M., R. Sousa, A. Bio, M. J. Araújo, C. Braga \& C. Antunes, 2014. Seasonal changes in fish assemblages in the River Minho tidal freshwater wetlands, NW of the Iberian Peninsula. Annales Limnologie-International Journal of Limnology 50: 185-198.

Palkovacs, E. P. \& D. M. Post, 2009. Experimental evidence that phenotypic divergence in predators drives community divergence in prey. Ecology 90: 300-305.

Palkovacs, E. P., M. C. Marshall, B. A. Lamphere, B. R. Lynch, D. J. Weese, D. F. Fraser, D. N. Reznick, C. M. Pringle \& M. T. Kinnison, 2009. Experimental evaluation of evolution and coevolution as agents of ecosystem change in Trinidadian streams. Philosophical Transactions of the Royal Society of London B: Biological Sciences 364: 1617-1628.

Palkovacs, E. P., D. C. Fryxell, N. E. Turley \& D. M. Post, 2015. Ecological effects of intraspecific consumer biodiversity for aquatic communities and ecosystems. In Aquatic Functional Biodiversity: 37-51.

Post, D. M., E. P. Palkovacs, E. G. Schielke \& S. I. Dodson, 2008. Intraspecific variation in a predator affects community structure and cascading trophic interactions. Ecology 89: 2019-2032.

Powell, M. L., H. S. Hammer \& S. A. Watts, 1998. Observations on the frequency of claw loss in the crayfish Procambarus charkii. Journal of the World Aquaculture Society 29: 485-490.

Reiss, J., R. A. Bailey, F. Cássio, G. Woodward \& C. Pascoal, 2010. Assessing the contribution of micro-organisms and macrofauna to biodiversity-ecosystem functioning relationships in freshwater microcosms. Advances in Ecological Research 43: 151-176.

Rudolf, V. H. W., N. L. Rasmussen, C. J. Dibble \& B. G. Van Allen, 2014. Resolving the roles of body size and species identity in driving functional diversity. Proceedings of the Royal Society B: Biological Sciences 281: 20133203.

Sih, A., J. Cote, M. Evans, S. Fogarty \& J. Pruitt, 2012. Ecological implications of behavioural syndromes. Ecology Letters 15: 278-289.

Simberloff, D., J. L. Martin, P. Genovesi, V. Maris, D. Wardle, J. Aronson, F. Courchamp, B. Galil, E. García-Berthou, M. Pascal, P. Pysek, R. Sousa, E. Tabacchi \& M. Vilà, 2013. Impacts of biological invasions: what's what and the way forward. Trends in Ecology and Evolution 28: 58-66. 
Singer, D., 2004. Metabolic adaptation to hypoxia: cost and benefit of being small. Respiratory Physiology \& Neurobiology 141: 215-228.

Smith, L. D. \& A. H. Hines, 1991. The effect of cheliped loss on blue crab Callinectes sapidus Rathbun foraging rate on soft-shell clams Mya arenaria L. Journal of Experimental Marine Biology and Ecology 151: 245-256.

Sousa, R., P. Morais, E. Dias \& C. Antunes, 2011. Biological invasions and ecosystem functioning: time to merge. Biological Invasions 13: 1055-1058.

Sousa, R., F. E. Freitas, M. Mota, A. J. Nogueira \& C. Antunes, 2013. Invasive dynamics of the crayfish Procambarus clarkii (Girard, 1852) in the international section of the River Minho (NW of the Iberian Peninsula). Aquatic Conservation: Marine and Freshwater Ecosystems 23: 656-666.

Souty-Grosset, C., P. M. Anastácio, L. Aquiloni, F. Banha, J. Choquer, C. Chucholl \& E. Tricarico, 2016. The red swamp crayfish Procambarus clarkii in Europe: impacts on aquatic ecosystems and human well-being. LimnologicaEcology and Management of Inland Waters 58: 78-93.
Stein, R. A. \& J. J. Magnuson, 1976. Behavioural response of crayfish to a fish predator. Ecology 57: 751-761.

Streissl, F. \& W. Hödl, 2002. Growth, morphometrics, size at maturity, sexual dimorphism and condition index of Austropotamobius torrentium Schrank. Hydrobiologia 477: 201-208.

Suberkropp, K., 1998. Microorganisms and organic matter decomposition. In Naiman, R. \& R. Bilby (eds), River Ecology and Management: Lessons from the Pacific Coastal Ecoregion. Springer, New York: 120-143.

Usio, N. \& C. R. Townsend, 2002. Functional significance of crayfish in stream food webs: roles of omnivory, substrate heterogeneity and sex. Oikos 98: 512-522.

Wipfli, M. S., J. S. Richardson \& R. J. Naiman, 2007. Ecological linkages between headwaters and downstream ecosystems: transport of organic matter, invertebrates, and wood down headwater channels. Journal of the American Water Resources Association 43: 72-85.

Zar, J. H., 2009. Biostatistical Analysis, 5th ed. Prentice-Hall, Englewood Cliffs. 